\title{
ELEVENTH ANNUAL LIST OF PAPERS
}

READ BEFORE THE AMERICAN MATHEMATICAL SOCIETY AND SUBSEQUEN'TLY PUBLISHED, INCLUDING REFERENCES

\author{
TO THE PLACES OF THEIR PUBLICATION.
}

Ames, L. D. Evaluation of Slowly Convergent Series. Read Apr. 26, 1902. Annals of Mathematics, 2 d ser., vol. 3, No. 4, pp. 185192 ; July, 1902.

BLACK, C. W. M. The Parametric Representation of the Neighborhood of a Singular Point of an Analytic Surface. Read Aug. 20, 1901. Proceedings of the American Academy of Arts and Sciences, vol. 37, No. 11, pp. 281-330; Jan., 1902.

BuIss, G. A. The Problem of the Calculus of Variations when the End Point is Variable. Read Aug. 19, 1901. Transactions of the American Mathematical Society, vol. 3, No. 1, pp. 132-141; Jan., 1902.

Bôcher, M. On Certain Pairs of Transcendental Functions whose Roots Separate each other. Read Aug. 19, 1901. Transactions of the American Mathematical Society, vol. 2, No. 4, pp. 428436 ; Oct., 1901.

On Wronskians of Functions of a Real Variable. Read Aug. 20, 1901. Bulletin of the American Mathematical Society, vol. 8, No. 2, pp. 53-63; Nov., 1901.

On the Real Solutions of Systems of Two Homogeneous Linear Differential Equations of the First Order. Read Dec. 27, 1901. Transactions of the American Mathematical Society, vol. 3, No. 2, pp. 196-215; April, 1902.

Borza, O. New Proof of a Theorem of Osgood in the Calculus of Variations. Read Aug. 19, 1901. Transactions of the American Mathematical Society, vol. 2, No. 4, pp. 422-427; Oct., 1901.

- Proof of the Sufficiency of Jacobi's Condition for a Permanent Sign of the Second Variation in the so-called Isoperimetric Problems. Read (Chicago) March 29, 1902. Transactions of the American Mathematical Society, vol. 3, No. 3, pp. 305-311; July, 1902.

Bromwrch, T. J. I'A. The Infinitesimal Generators of Parameter Groups. Read April 26, 1902. Bulletin of the American Mathematical Society, vol. 8, No. 9, pp. 375-386; June, 1902.

- On the Parabolas (or Paraboloids) through the Points Common to Two Given Conics (or Quadrics). Read April 26, 1902. Bulletin of the American Mathematical Society, vol. 8, No. 9, pp. 386-388; June, 1902.

Brown, E. W. Modern Methods of Treating Dynamical Problems and in Particular the Problem of Three Bodies. Read August 21-24, 1901. Bulletin of the American Mathematical Society, vol. 8, No. 3, pp. 103-113; Dec., 1901.

- On the Small Divisors in the Lunar Theory. Read Feb. 22, 1902. Transactions of the American Mathematical Society, vol. 3, No. 2, pp. 159-185; April, 1902. 
Curtiss, D. R. Note on the Sufficient Conditions for an Analytic Function. Read April 26, 1902. Bulletin of the American Mathematical Society, vol. 8, No. 8, pp. 329-331; May, 1902.

Dickson, L. E. Theory of Linear Groups in an Arbitrary Field. Read Aug. 20, 1901. Transactions of the American Mathematical Society, vol. 2, No. 4, pp. 363-394; Oct., 1901.

The Configurations of the 27 Lines on a Cubic Surface and the 28 Bitangents to a Quartic Curve. Read Aug. 20, 1901. Bulletin of the American Mathematical Society, vol. 8, No. 2, pp. 6370 ; Nov., 1901.

- Representation of Linear Groups as Transitive Substitution Groups. Read (Chicago) April 6, 1901. American Journal of Mathematics, vol. 23, No. 4, pp. 337-377; Oct., 1901. See, also, The Groups of Steiner in Problems of Contact, Transactions of the American Mathematioal Society, vol. 3, No. 1, pp. 38-45; Jan., 1902.

- On the Group Defined by Any Given Field by the Multiplication Table of Any Given Finite Group. Read (Chicago) March 29, 1902. Transactions of the American Mathematical Society, vol. 3, No. 3, pp. 285-301; July, 1902.

- The Groups of Steiner in Problems of Contact (Second Paper). Read Feb. 22, 1902. Transactions of the American Mathematical Society, vol. 3, No. 3, pp. 377-382; July, 1902.

Dunkel, O. Some Applications of Green's Theorem in One Dimension. Read Feb. 22, 1902. Bulletin of the American Mathematical Society, vol. 8, No. 7, pp. 288-292; April, 1902.

Eisenhart, L. P. Lines of Length Zero on Surfaces. Read Dec. 28, 1901. Bulletin of the American Mathematical Society, vol. 8, No. 6, pp. 241-243; March, 1902.

- Note on Isotropic Congruences. Read Dec. 28, 1901. Bulletin of the American Mathematical Society, vol. 8, No. 7, pp. 301303 ; April, 1902.

- Conjugate Rectilinear Congruences. Read Oct. 26, 1901. Transactions of the American Mathematical Society, vol. 3, No. 3, pp. 354-371; July, 1902.

EмcH, A. Note on Congruences of Twisted Curves. Read (Chicago) Dec. 27, 1900. The University of Colorado Studies, vol. 1, No. 1, pp. 29-32; Jan., 1902.

- Some Applications of the Theory of Assemblages. Read Dec. 28, 1901. Mathematical Gazette, vol. 2, No. 33, pp. 173-175; May, 1902.

EPSTEEn, S. Proof that the Group of an Irreducible Linear Differential Equation is Transitive. Read Dec. 28, 1901. Bulletin of the American Mathematical Society, vol. 8, No. 6, pp. 239-241; March, 1902.

FIELDS, J. C. The Riemann-Roch Theorem and the Independence of the Conditions of Adjointness in the case of a Curve in which the Tangents at the Multiple Points are Distinct from one another. Read Aug. 19, 1901. Journal für reine und angewandte Mathematik (Crelle), vol. 124, No. 3, pp. 179-201; March, 1902. 
Frte, W. B. Concerning the Class of a Group of Order $p^{m}$ that contains an Operator of Order $p^{m-2}$ or $p^{m-3}, p$ being a Prime. Read Dec. 28, 1901. Bulletin of the American Mathematical Society, vol. 8, No. 6, pp. 236-239. March, 1902.

On Metabelian Groups. Read Aug. 26, Dec. 28, 1899, and Feb. 23, 1901. Transactions of the American Mathematical Society, vol. 3, No. 3, pp. 331-353; July, 1902.

Granville, W. A. Invariants of Some $m$-gons under Certain Projective Lie Groups in the Plane. Read April 27, 1901. Annals of Mathematics, $2 \mathrm{~d}$ ser., vol. 3, No. 1, pp. 43-44; Oct., 1901.

Hancock, H. On Primary Prime Functions in Several Variables, and a Generalization of an Important Theorem of Dedekind. Read Dec. 28, 1900. American Journal of Mathematics, vol. 24, No. 1, pp. 39-60; Jan., 1902.

Haskins, C. N. On the Invariants of Quadratic Differential Forms. Read Aug. 20, 1901. Transactions of the American Mathematical Society, vol. 3, No. 1, pp. 71-91; Jan., 1902.

Hathaway, A. S. Quaternions and Fourfold Space. Read (Chicago) Dec. 27, 1900. Transactions of the American Mathematical Society, vol. 3, No. 1, pp. 46-59; Jan., 1902.

Hawkes, H. E. Estimate of Benjamin Peirce's Linear Associative Algebra. Read Feb. 23, 1901. American Journal of Mathematics, vol. 24, No. 1, pp. 87-95; Jan., 1902.

On Hypercomplex Number Systems. Read June 28, 1900. Transactions of the American Mathematical Society, vol. 3, No. 3, pp. 312-330; July, 1902.

Huntington, E. V. A Complete Set of Postulates for the Theory of Absolute Continuous Magnitude. Read Feb. 22, 1902. Transactions of the American Mathematical Society, vol. 3, No. 2, pp. 264-279; April, 1902.

- Complete Sets of Postulates for the Theories of Positive Integral and Positive Rational Numbers. Read Feb. 22, 1902. Transactions of the American Mathematical Society, vol. 3, No. 2, pp. 280-284; April, 1902.

- Simplified Definition of a Group. Read Feb. 22, 1902. Bulletin of the American Mathematical Society, vol. 8, No. 7, pp. 296300; April, 1902.

A Second Definition of a Group. Read April 26, 1902. Bulletin of the American Mathematical Society, vol. 8, No. 9, pp. 388391 ; June, 1902.

- and Whitremore, J. K. Some Curious Properties of Conics Touching the Line Infinity at One of the Circular Points. Read Oct. 26, 1901. Bulletin of the American Mathematical Society, vol. 8, No. 3, pp. 122-124; Dec., 1901. Cf. p. 419; June, 1902.

Hutchinson, J. I. On a Class of Automorphic Functions. Read Aug. 19, 1901. Transactions of the American Mathematical Society, vol. 3, No. 1, pp. 1-11; Jan., 1902.

Kasner, E. The Algebraic Potential Surfaces. Read April 27, 1901. Bulletin of the American Mathematical Society, vol. 8, No. 6, pp. 243-248; March, 1902. 
Keyser, C. J. Concerning the Angles and the Angular Determination of Planes in 4-Space. Read April 26, 1902. Bulletin of the American Mathematical Society, vol. 8, No. 8, pp. 324-329; May, 1902.

LeHMER, D. N. Constructive Theory of the Unicursal Cubic by Synthetic Methods. Read (San Francisco) May 3, 1902. Transactions of the American Mathematical Society, vol. 3, No. 3, pp. 372-376; July, 1902.

Lemoine, E. Note sur la Construction approchée de $\pi$ de $\mathbf{M r}$. George Peirce. Read Aug. 20, 1901. Bulletin of the American Mathematical Society, vol. 8, No. 4, pp. 137-148; Jan., 1902.

Lovetr, E. O. On Geometry of $n$ Dimensions. Read Oct. 27, Dec. 28, 1900, Feb. 23, April 27, 1901. Journal de Mathématiques, 5th ser., vol. 7, no. 3, pp. 259-303; Jan., 1902.

Contact Transformations between the Fundamental Elements of Space. Read Oct. 27, Dec. 28, 1900; Feb. 23, 1901. Annali di Matematica, 3d ser., vol. 7, no. 1, pp. 39-98; Jan., 1902.

McCuntock, E. On the Nature and Use of the Functions employed in the Recognition of Quadratic Residues. Read Dec. 27, 1901. Transactions of the American Mathematical Society, vol. 3, No. 1, pp. 92-109; Jan., 1902.

MoDonald, J. H. The Reduction of Hyperelliptic Integrals of Genus Two to Elliptic Integrals by a Transformation of Order Four. Read (Chicago) April 6, 1901. Transactions of the American Mathematical Society, vol. 2, No. 4, pp. 437-458; Oct., 1901.

Metzler, W. H. On Certain Aggregates of Determinant Minors. Read April 27, 1901. Transactions of the American Mathematical Society, vol. 2, No. 4, pp. 395-403; Oct., 1901.

Mrluer, G. A. Groups defined by the Orders of Two Generators and the Order of their Product. Read Aug. 20, 1901. American Journal of Mathematics, vol. 24, No. 1, pp. 96-100; Jan., 1902.

On the Abelian Groups which are Conformal with Non-Abelian Groups. Read Oct. 26, 1901. Bulletin of the American Mathematical Society, vol. 8, No. 4, pp. 154-156; Jan., 1902.

Determination of All the Groups of Order $p^{m}, p$ being any Prime, which Contain the Abelian Group of Order $p^{m-1}$ and of Type $(1,1,1, \ldots)$. Read (San Francisco) May 3, 1902. Bulletin of the American Mathematical Society, vol. 8, No. 9, pp. 391-394; June, 1902.

MooRe, E. H. On the Theory of Improper Definite Integrals. Read Aug. 19, 1901. Transactions of the American Mathematical Society, vol. 2, No. 4, pp. 459-475; Oct., 1901.

On the Projective Axioms of Geometry. Read Dec. 28, 1901. Transactions of the American Mathematical Society, vol. 3, No. 1, pp. 142-158; Jan., 1902.

MoRItz, R. E. A Generalization of the Process of Differentiation. Read (Chicago) Dec. 28, 1899. American Journal of Mathematics, vol. 27, No. 3, pp. 257-302; July, 1902. 
Moulton, F. R. A Simple Non-Arguesian Geometry. Read (Chicago) Jan. 2, 1902. Transactions of the American Mathematical Society, vol. 3, No. 2, pp. 192-195; April, 1902.

Newson, H. B. On the Group of 216 Collineations of the Plane. Read (Chicago) April 14, 1900. Kansas University Quarterly, ser. A, vol. 10, No. 1, pp. 13-32; Jan., 1901.

On the Product of Linear Substitutions. Read (Chicago) Jan. 3, 1902. Annals of Mathematics, 2d ser., vol. 3, No. 3, pp. 147148 ; April, 1902.

Pecl, A. Some Remarks on Surfaces whose First and Second Fundamental Forms are the Second and First respectively of Another Surface. Read Aug. 20, 1901. Bulletin of the American Mathematical Society, vol. 8, No. 1, pp. 27-28; Oct., 1901.

Porter, M. B. On Linear Homogeneous Finite Difference Equations, with Applications to Certain Theorems of Sturm. Read Feb. 23, 1901. Annals of Mathematics, $2 \mathrm{~d}$ ser., vol. 3, No. 2, pp. 5570 ; Jan., 1902.

Pringsheim, A. Ueber die Anwendung der Cauchy'schen Multiplicationsregel auf bedingt convergente oder divergente Reihen. Read Aug. 19, 1901. Transactions of the American Mathematical Society, vol. 2, No. 4, pp. 404-412; Oct., 1901.

- Ueber den Goursat'schen Beweis des Cauchy'schen Integralsatzes. Read Aug. 19, 1901. Transactions of the American Mathematical Society, vol. 2, No. 4, pp. 413-421; Oct., 1901.

Roever, W. H. Brilliant Points and Loci of Brilliant Points. Read Feb. 22, 1902. Annals of Mathematics, 2d ser., vol. 3, No. 3, pp. 113-128; April, 1902.

SchotTenfels, I. M. Upon the Non-Isomorphism of two Simple Groups of Order 8!/2. Read Aug. 20, 1901. Bulletin of the American Mathematical Society, vol. 8, No. 1, pp. 25-26; Oct., 1901.

Scotт, C. A. A recent Method for Treating the Intersections of Plane Curves. Read Dec. 27, 1901. Transactions of the American Mathematical Society, vol. 3, No. 2, pp. 216-263; April, 1902.

Slocum, S. E. The Symbols of the Infinitesimal Transformations which Generate the Parameter Groups corresponding to all possible Types of Structure of Two, Three and Four Parameter Complex Groups. Read Oct. 26, 1901. Bulletin of the American Mathematical Society, vol. 8, No. 4, pp. 156-168; Jan., 1902.

- Note on the Transformation of a Group into its Canonical Form. Read Dec. 28, 1901. Bulletin of the American Mathematical Society, vol. 8, No. 7, pp. 280-288; April, 1902.

ENyder, V. On the Forms of Quintic Scrolls. Read Feb. 22, 1902. Bulletin of the American Mathematical Society, vol. 8, No. 7, pp. 293-296; April, 1902.

Stecker, H. F. On the Determination of Surfaces Capable of Conformal Representation upon the Plane so that the Geodetic Lines shall be represented by a Prescribed System of Plane Curves. Read Aug. 19, 1901. Transactions of the American Mathematical Society, vol. 3, No. 1, pp. 12-22; Jan., 1902. 
Concerning the Elliptic $\wp\left(g_{2} ; g_{3} ; z\right)$-Functions as Coördinates in a Line Complex, and certain Related Theorems. Read Oct. 26, 1901. Bulletin of the American Mathematical Society, vol. 8, No. 4, pp. 148-153; Jan., 1902.

SToLz, O. Zur Erklärung der Bogenlänge und des Inhaltes einer krümmen Fläche. Read Oct. 26, 1901. Transactions of the American Mathematical Society, vol. 3, No. 1, pp. 23-37; Jan., 1902.

_ Nachtrag zum Artikel: "Zur Erklärung der Bogenlänge, u. s. w." Read (Chicago) March 29, 1902. Transactions of the American Mathematical Society, vol. 3, No. 3, pp. 302-304; July, 1902.

VAN Vreck, E. B. A Proof of the Convergence of the Gaussian Continued Fraction for $F(\alpha, \beta+1, \gamma+1, x) / F(\alpha, \beta, \gamma, x)$. Read Aug. 20, 1901. Transactions of the American Mathematical Society, vol. 2, No. 4, pp. 476-483; Oct., 1901; and Annals of Mathematics, 2 d ser., vol. 3, No. 1, pp. 1-18; Oct., 1901.

On the Zeros of Fundamental Integrals of Regular Linear Differential Equations of the Second Order, with a Determination of the Number of Imaginary Roots of the Hypergeometric Series. Read Oct. 26, 1901. Transactions of the American Mathematical Society, vol. 3, No. 1, pp. 110-131; Jan., 1902.

Westrund, J. Note on Multiply Perfect Numbers. Read (Chicago) Jan. 3, 1902. Annals of Mathematics, 2d ser., vol. 3, No. 4, pp. 161-163; July, 1902.

Whrte, H. S. Note on a Twisted Curve connected with an Involution of Pairs of Points in a Plane. Read (Chicago) Jan. 2, 1902. Annals of Mathematics, 2 d ser., vol. 3, No. 4, pp. 149153 ; July, 1902.

Whittemore, J. K. See Huntington, E. V.

WILczYNskI, E. J. Invariants of Systems of Linear Differential Equations. Read Oct. 27, 1900. Transactions of the American Mathematical Society, vol. 2, No. 1, pp. 1-24; Jan., 1901.

Geometry of a Simultaneous System of Two Linear Homogeneous Differential Equations of the Second Order. Read April 27, 1901. Transactions of the American Mathematical Society, vol. 2, No. 4, pp. 343-362; Oct., 1901.

Reciprocal Systems of Linear Differential Equations. Read Oct. 26, 1901. Transactions of the American Mathematical Society, vol. 3, No. 1, pp. 60-70; Jan., 1902.

Young, J. W. On the Holomorphisms of a Group. Read Dec. 28, 1901. Transactions of the American Mathematical Society, vol. 3, No. 2, pp. 186-191; April, 1902. 